\title{
No Evidence of BRCAl/2 Genomic Rearrangements in High-Risk French-Canadian Breast/Ovarian Cancer Families
}

\author{
ANNE-MARIE MOISAN,${ }^{1}$ JESSYKA FORTIN, ${ }^{1}$ MARTINE DUMONT, ${ }^{1}$ CAROLLE SAMSON,${ }^{1}$ \\ PAUL BESSETTE, ${ }^{2}$ JOCELYNE CHIQUETTE,${ }^{3}$ RACHEL LAFRAMBOISE,${ }^{4}$ JEAN LÉPINE, ${ }^{5}$ \\ BERNARD LESPÉRANCE, ${ }^{6}$ ROXANE PICHETTE, ${ }^{6}$ MARIE PLANTE, ${ }^{7}$ LOUISE PROVENCHER, ${ }^{3}$ \\ PATRICIA VOYER,${ }^{8}$ DAVID GOLDGAR, ${ }^{9}$ PETER BRIDGE,${ }^{10}$ and JACQUES SIMARD ${ }^{1,11}$
}

\begin{abstract}
The discovery of deleterious mutations in the breast and ovarian cancer susceptibility genes, BRCA1 and $B R C A 2$, has facilitated the identification of individuals at particularly high risk of these diseases. There is a wide variation between populations in the prevalence and related risks of various types of $B R C A 1 / 2$ mutations, so estimates cannot be extrapolated to Canadians, especially not founder populations such as FrenchCanadians. Polymerase chain reaction (PCR)-based methods were used to detect the majority of these mutations. These approaches usually failed to detect large DNA rearrangements, which have been claimed to be involved in other populations in $5 \%$ to up to $36 \%$ of $B R C A 1$-positive families. There is very little information about the contribution of this type of mutation in BRCA2-positive families. To investigate if our available mutation spectrum of $B R C A 1$ and $B R C A 2$ in high-risk French-Canadian breast/ovarian cancer families has been biased by PCR-based direct sequencing methods, we first used Southern blot analysis to test DNA samples from 61 affected/obligate carrier individuals from 58 families in which no BRCA1/2 deleterious mutation was found. Finally, 154 individuals from 135 BRCA1/2 nonconclusive families, including all those tested previously by Southern blot analysis, were tested with the new multiplex ligation probe amplification (MLPA) technique. These approaches failed to detect any rearrangement. Moreover, if the frequency of MLPA-detectable rearrangements in our cohort of 135 BRCA1/2 nonconclusive families was $2.2 \%$ or higher, we would have had a $95 \%$ or greater chance of observing at least one such rearrangement. As no rearrangements were identified, such large rearrangements must be quite rare in our population.
\end{abstract}

\section{INTRODUCTION}

N MANY DEVELOPED COUNTRIES, breast cancer is the most common malignancy among women with nearly 1,000,000 new cases per year (Key et al. 2001; Lacey et al. 2002; Pisani et al. 1999). In the race to decrease breast cancer mortality, early de- tection and improved treatment have emerged as the most critical strategies. The potential for early detection using genetic indicators is crucial, because positive family history is second only to age as the strongest epidemiologic risk factor for breast cancer. Twin studies indicate that inherited susceptibility, rather than lifestyle or environmental factors, is responsible for most

\footnotetext{
${ }^{1}$ Cancer Genomics Laboratory, Oncology and Molecular Endocrinology Research Center, Centre Hospitalier Universitaire de Québec, and Laval University, Québec.

${ }^{2}$ Department of Obstetrics and Gynecology, Centre Hospitalier Universitaire de Sherbrooke, Sherbrooke.

${ }^{3}$ Centre des maladies du sein Deschènes-Fabia, Hôpital Saint-Sacrement, CHA, Québec

${ }^{4}$ Clinical Genetic Division, Centre Hospitalier Universitaire de Québec, and Laval University, Québec.

${ }^{5}$ Service of Haemato-Oncology, Centre hospitalier régional de Rimouski, Rimouski.

${ }^{6}$ Department of Haemato-Oncology, Hôpital du Sacré-Cœur de Montréal, Montréal.

${ }^{7}$ Gynecologic Oncology Division, Hôtel-Dieu de Québec, Centre Hospitalier Universitaire de Québec, and Laval University, Québec.

${ }^{8}$ Clinique des maladies du sein, Carrefour de Santé de Jonquière, Jonquière.

${ }^{9}$ Department of Dermatology, University of Utah School of Medicine, Salt Lake City, Utah.

${ }^{10}$ Molecular Diagnostic Laboratory, Alberta Children's Hospital, Calgary.

${ }^{11}$ Canada Research Chair in Oncogenetics, Department of Anatomy-Physiology, Faculty of Medicine, Laval University, Québec.
} 
familial aggregation (Lichtenstein et al. 2000; Peto 2001). In part, this is explained by specific familial cancer syndromes in which variants of single genes confer a high risk of disease. BRCA1 (MIM 113705) and BRCA2 (MIM 600185) are the two major known genes that cause a genetic susceptibility to breast and ovarian cancer (Miki et al. 1994; Tavtigian et al. 1996; Wooster et al. 1995).

There are wide variations between populations in the prevalence and related risks of BRCA1/2 mutations so estimates cannot be extrapolated to Canadians, especially to the founder French-Canadian population, which possesses unique genealogical characteristics. Furthermore, the identification of founder mutations in specific populations has been shown to dramatically reduce the cost and technical limitations of testing. One of the main objectives of the Interdisciplinary Health Research International Team on Breast Cancer susceptibility (INHERIT BRCAs) research program was to estimate the prevalence of deleterious BRCA1 and BRCA2 mutations in this founder population in order to improve predictive genetic testing utility and genetic counseling to affected as well as asymptomatic individuals (Simard et al. 2004, 2005).

In other populations, several large genomic rearrangements were detected in $B R C A 1$, which have frequently been attributed to unequal homologous recombination within Alu repeats (for a review see Mazoyer 2005); in contrast, only 8 rearrangements have been reported in BRCA2. For instance, the BRCA1 gene contains 129 Alu elements, which is equivalent to $41.5 \%$ of its sequence (Pavlicek et al. 2004; Smith et al. 1996). This relatively high density of $A l u$ repeats appears to be the main source of large genomic rearrangements identified so far, involving at least 26 different high-risk $A l u$ elements that have been remarkably stable throughout the hominoid primates (Pavlicek et al. 2004). The presence of the $B R C A 1$ pseudogene upstream of $B R C A 1$, in which exons $1 \mathrm{a}, 1 \mathrm{~b}$, and 2 are duplicated, represents an additional source of rearrangements caused by unequal homologous recombination (Puget et al. 2002). The proportion of all pathogenic $B R C A 1 / 2$ mutations arising from genomic rearrangements has been estimated to be approximately $10 \%$ to $15 \%$, but founder effects have been reported in some populations, thus resulting in higher frequencies of such mutations (Gad et al. 2002; Petrij-Bosch et al. 1997).

To assess the importance of BRCA1 and BRCA2 alterations that could be missed by standard polymerase chain reaction (PCR)-based screening techniques, we looked for germline rearrangements in high-risk French-Canadian breast and/or ovarian cancer families. We searched for rearrangements using both Southern blot and multiplex ligation-dependent probe amplification (MLPA) methods.

\section{MATERIALS AND METHODS}

\section{Ascertainment of families}

The recruitment of high-risk French-Canadian breast and/or ovarian families started in 1996 through a research project, which thereafter evolved into a large ongoing interdisciplinary research program designated INHERIT BRCAs (Avard et al. 2005; Simard et al. 2005; J. Simard et al., unpublished data, 2006). A major component was to identify and characterize
BRCA1 and BRCA2 mutations in the French-Canadian population and to determine the role of the demographic history in their origin and diffusion. This integrated clinical research program was composed of a network of referring clinicians across the province of Québec. After pretest education sessions and detailed analysis of familial history, a total of 251 (counted as 256 in total because 5 families had a history of cancer on both sides that met the criteria of eligibility mentioned below) highrisk French-Canadian breast/ovarian cancer families were recruited according to strict criteria: (1) families with at least four individuals with breast and/or ovarian cancer diagnosed in firstor second-degree relatives; (2) families presenting three individuals with breast and/or ovarian cancer in first-degree relatives; and (3) families bearing a mutation already identified in the $B R C A 1$ or $B R C A 2$ gene. These families have been classified in two groups. A subset of 191 families (subset A) for which at least one DNA sample from a woman affected with breast and/or ovarian cancer was available for genetic testing and a subset consisting of 65 families (subset B), for which only asymptomatic individuals were available. All participants had to be at least 18 years of age and mentally capable. In most instances, the diagnoses of breast and/or ovarian cancer were confirmed by obtaining a pathology report. Clinicians involved in this research program were responsible for $B R C A 1 / 2$ test result disclosure to participants. Approval was obtained from eight ethics committees corresponding to the different institutions participating in the research program.

\section{Prior mutation testing by partial and full-length sequencing}

Participants entering the study were first tested for a panel of mutations known to occur in the French-Canadian population. At the present time DNA samples from participants have been tested for a panel of 29 mutations including 26 truncating mutations and 3 unclassified variants. This first step approach led to the discovery of deleterious mutations in 54 different families (Simard et al. 2004; J. Simard et al., unpublished data, 2006). For each family that received a $B R C A 1 / 2$ nonconclusive result (i.e., no mutation was found by screening for the panel of mutations analyzed in the first step), at least one DNA sample from a woman affected with breast and/or ovarian cancer (with the exception of four DNA samples from an unaffected parent from whom the familial breast/ovarian cancer history derived) was sent to Myriad Genetic Laboratories, Salt Lake City, Utah, for full-length BRCA1/BRCA2 sequencing following their Comprehensive BRACAnalysis ${ }^{\circledR}$-BRCA1 and BRCA2 gene sequence analysis for susceptibility to breast and ovarian cancer test. Testing services were performed according to the Memorandum of Understanding (MOU) with the National Cancer Institute (NCI) for NCI-funded research testing services for BRCA1 and BRCA2 (project no. NCI 173). The second step screening approach led to the discovery of eight novel mutations found in eight different families (Simard et al. 2004). For each individual belonging to a $B R C A 1 / 2$-positive family, a confirmation test has been performed on a second blood sample by the Molecular Diagnostic Laboratory, Alberta Children's Hospital, Calgary. More details concerning the results obtained in this cohort will be described elsewhere (J. Simard et al., unpublished data, 2006). From subset A, including 191 families 
in which at least one DNA sample was available from an affected woman, 135 families remained $B R C A 1 / 2$ nonconclusive after the two-step analyses described above, whereas 59 were $B R C A 1 / 2$ nonconclusive in the subset B including 65 families in which only asymptomatic individuals were available for testing (Simard et al. 2004; J. Simard et al., unpublished data, 2006). All DNA samples analyzed in the present study belong to subset A. The breast and ovarian cancer history of the 135 BRCA1/2 nonconclusive families are described in Table 1.

\section{DNA and RNA samples}

After obtaining signed informed consent from each participant, $40 \mathrm{ml}$ of blood was drawn and genomic DNA was extracted using the guanidine hydrochloride-proteinase K method and the QIAmp Maxi blood kit following the manufacturer's instructions (QIAGEN, Mississauga, Ontario, Canada). Epstein-Barr virus (EBV)-transformed B-lymphoblastoid cell lines were established. DNA from lymphoblastoid cell lines was extracted using the cetyltrimethylammonium bromide (CTAB) protocol (Del Sal et al. 1989). RNA was extracted using TRIZOL (Invitrogen, Gibco BRL, Carlsbad, CA) according to the manufacturer's instructions and reverse transcription of RNA was performed using $10 \mu \mathrm{g}$ of total RNA with SuperScript ${ }^{\mathrm{TM}}$ II Rnase $\mathrm{H}^{-}$Reverse Transcriptase and an oligo $\mathrm{dT}_{12-18}$ primer (Invitrogen) as directed by the supplier's protocol. PCR was done using primers (available on request) to verify the presence of small exons 3 and 20 for BRCA1 and 2-6, 8, 12, 13, 17, 21, and 26 for BRCA2.

\section{Southern blot analysis}

We first performed Southern blot analysis with genomic DNA from lymphoblastoid cell lines of 61 individuals belonging to $58 \mathrm{BRCA1/2}$ nonconclusive families as well as 30 indi-

Table 1. Distribution of the 135 BRCA1/2 Nonconclusive Families Following Their Breast and Ovarian Cancer History at 2ND, 3RD, OR 4th Degree from the INDEX CASE

\begin{tabular}{lcrrr}
\hline & & \multicolumn{3}{c}{$\begin{array}{c}\text { Degree from the } \\
\text { index case }\end{array}$} \\
\cline { 3 - 5 } $\begin{array}{l}\text { Breast cancer } \\
\text { cases (n) }\end{array}$ & $\begin{array}{c}\text { Ovarian cancer } \\
\text { cases (n) }\end{array}$ & 2 2nd & $3 r d$ & 4 th \\
\hline$\leq 2$ & 0 & 11 & 3 & 1 \\
3 & $\geq 1$ & 11 & 9 & 7 \\
& 0 & 29 & 19 & 17 \\
4 & $\geq 1$ & 5 & 5 & 4 \\
& 0 & 35 & 21 & 17 \\
5 & $\geq 1$ & 4 & 6 & 7 \\
6 & 0 & 23 & 28 & 28 \\
& $\geq 1$ & 3 & 6 & 6 \\
$\geq 7$ & 0 & 6 & 13 & 18 \\
& $\geq 1$ & 1 & 2 & 4 \\
& 0 & 6 & 18 & 19 \\
& $\geq 1$ & 1 & 5 & 7 \\
& & 135 & 135 & 135 \\
\hline
\end{tabular}

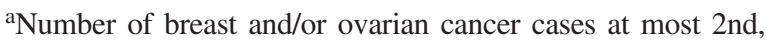
3 rd, or 4th degree from the index cases, which are the first recruited and tested individuals of a family. viduals from 28 BRCA1/2-positive families as control. Digestions were performed with $15 \mu \mathrm{g}$ of genomic DNA from lymphoblastoid cell lines overnight with approximately 100 units of AvaII, PstI and TaqI for BRCAI and AvaII, HindIII, and TaqI for BRCA2. Following a standard $\mathrm{NaOAc}$ precipitation, digestions were run overnight on a $0.8 \%$ agarose gel at $45 \mathrm{~V}$ in $1 \times$ tris-borate EDTA buffer (TBE). Gels were partially depurinated in $0.25 \mathrm{~N} \mathrm{HCl}$ for $15 \mathrm{~min}$ and denatured in $0.4 \mathrm{~N} \mathrm{NaOH} / 0.6 \mathrm{~N}$ $\mathrm{NaCl}$ for 30 min with gentle shaking. DNA was transferred to a GeneScreen Plus nylon membrane (NEN, Boston, MA) overnight in the $10 \times \mathrm{SSC}$ alkaline buffer. The blots were prehybridized at $42^{\circ} \mathrm{C}$ for $2 \mathrm{hr}$ with $50 \%$ formamide, $2 \times \mathrm{SSC}, 1 \%$ sodium dodecyl sulfate (SDS), $10 \%$ dextran sulfate, and $5 \times$ Denhardt's solution. Thereafter, denatured salmon sperm DNA $(0.2 \mathrm{mg} / \mathrm{ml})$ was included with $1 \times 10^{6} \mathrm{cpm} / \mathrm{ml}$ of a ${ }^{32} \mathrm{P}$-labeled cDNA probe in the solution for an overnight hybridization. The probes were obtained by digestion of plasmid DNA containing the entire $B R C A 1$ or $B R C A 2$ coding region (Figs. 1 and 2). Fifty nanograms of cDNA fragment corresponding to EcoRV-Bam HI fragment covering BRCA1 exons 2-11 (nt 120-4058); BamHISacI fragment covering BRCAl exons 11-24 (nt 4058-7140) according to U14680; NdeI fragments of BRCA2 covering exons 2-10 (nt 229-1796); exon 10-17 (nt 1796-8110); exon 17-27 (nt 8110-10,775) according to U43746, were labeled a using Random Primed DNA Labeling kit following the supplier's protocol (Roche Applied Science, Mannheim, Germany). After hybridization, the membrane was washed at room temperature for $10 \mathrm{~min}$ in $2 \times \mathrm{SSC}, 30 \mathrm{~min}$ at $65^{\circ} \mathrm{C}$ in $2 \times$ $\mathrm{SSC} / 0.1 \% \mathrm{SDS}$ and $30 \mathrm{~min}$ at $65^{\circ} \mathrm{C}$ in $0.1 \times \mathrm{SSC} / 0.1 \% \mathrm{SDS}$. Filters were exposed for $24 \mathrm{~h}$ and scanned with a Phosphorimager (Molecular Dynamics, Sunnyvale, CA), and thereafter exposed for 10 days to X-ray single emulsion film (Kodak BioMax MR Film, Rochester, NY) with an intensifying screen $(\mathrm{NEN})$ at $-80^{\circ} \mathrm{C}$ and developed.

\section{MLPA analysis}

We performed MLPA analysis with genomic DNA samples from 154 individuals belonging to the 135 BRCA1/2 nonconclusive families as well as 39 individuals who belong to 32 $B R C A 1 / 2$-positive families as control, using the SALSA P002 human BRCA1 and P045 human BRCA2 test kits, respectively (MRC-Holland, Amsterdam, The Netherlands). Moreover, we have used as positive controls for MLPA analysis, DNA from individual carrying rearrangements in BRCA1, namely, deletion of exons 1a-1b-2 (Puget et al. 2002), deletion of exon 17 (Puget et al. 1997), and duplication of exon 13 (Puget et al. 1999a), which were kindly provided by Dr. Olga Sinilnikova from Centre Léon Bérard, Lyon, France. One hundred nanograms of genomic DNA were diluted with $1 \times$ TE in 5 ul and were heated at $98^{\circ} \mathrm{C}$ for $5 \mathrm{~min}$. After adding $1.5 \mu \mathrm{l}$ salt solution $(1.5 \mathrm{M} \mathrm{KCl}$, $300 \mathrm{mM}$ Tris- $\mathrm{HCl} \mathrm{pH} 8.5,1 \mathrm{mM}$ EDTA), samples were mixed with $1.5 \mu \mathrm{l}$ probe mix, heated for $1 \mathrm{~min}$ at $95^{\circ} \mathrm{C}$, and then incubated for $16 \mathrm{hr}$ at $60^{\circ} \mathrm{C}$. Ligation of annealed primers was performed by adding $32 \mu$ ligase- 65 mix and incubating for 15 $\min$ at $54^{\circ} \mathrm{C}$. The ligase enzyme was inactivated by heating 5 $\min$ at $98^{\circ} \mathrm{C}$. A $10-\mu l$ aliquot of the ligation reaction was mixed with $30 \mu \mathrm{l}$ of PCR buffer. While the samples were at $60^{\circ} \mathrm{C}$, a mix of primers $\mathrm{X}$ and $\mathrm{Y}$ (Fam labeled), dNTPs, and SALSA polymerase was added. PCR was performed for 33 cycles (30 


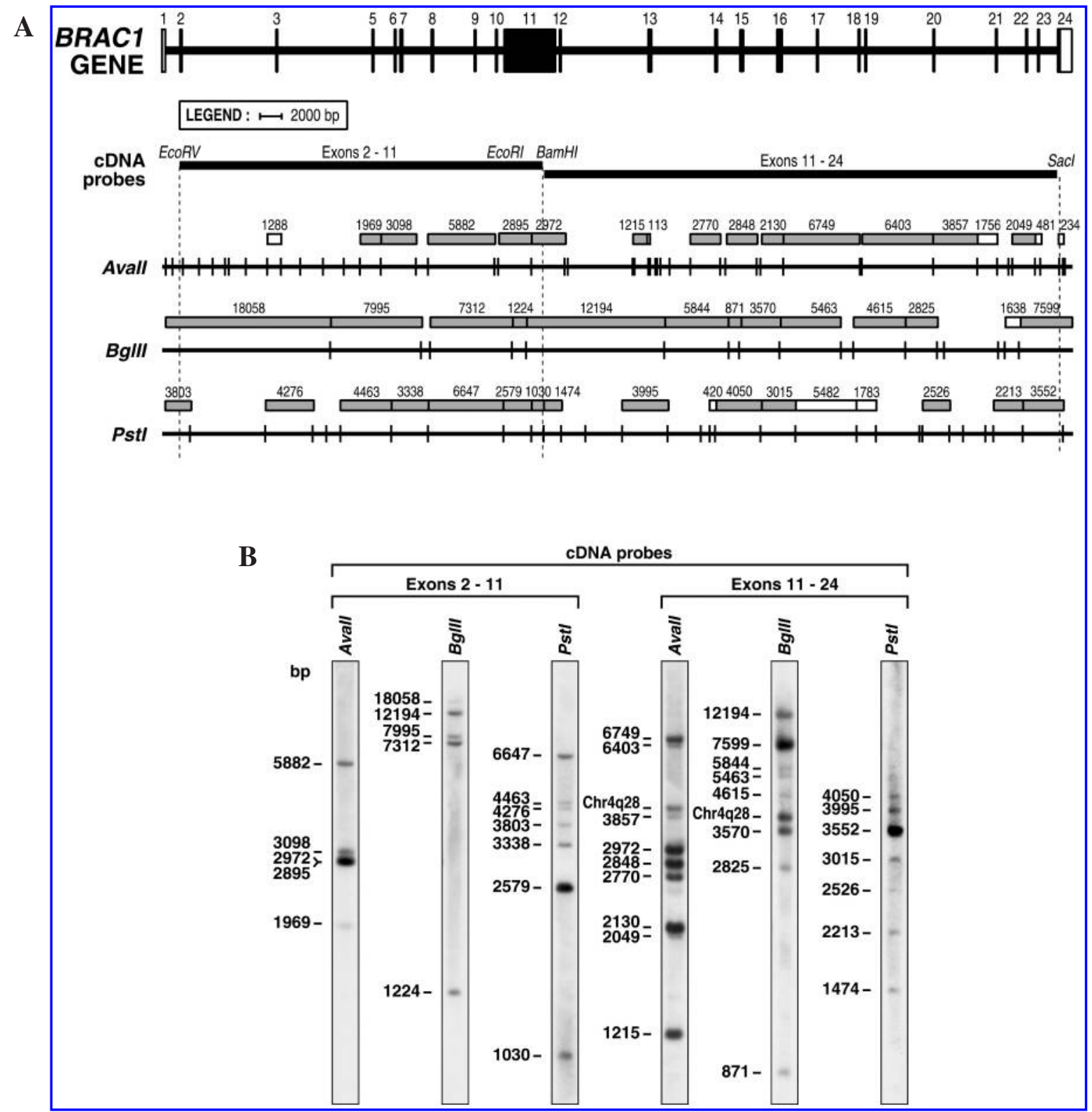

FIG. 1. Southern blot analyses of the BRCAl gene. A: Restriction sites are indicated on the gene structure and BRCA1 probes used in the Southern blot analyses and sizes (in base pairs [bp]) of restriction fragments expected to be revealed by the probes are indicated in grey boxes. Open boxes represent the fragments not detectable using this Southern blot analysis strategy. B: Results from typical Southern blot analyses of the BRCAl gene. Fifteen micrograms of genomic DNA was digested by three restriction enzymes for each probes and exposed for 10 days to $\mathrm{x}$-ray single emulsion film with an intensifying screen at $-80^{\circ} \mathrm{C}$.

sec at $95^{\circ} \mathrm{C}, 30$ seconds at $60^{\circ} \mathrm{C}$, and $1 \mathrm{~min}$ at $\left.72^{\circ} \mathrm{C}\right)$. Samples were analyzed using a capillary electrophoresis system (ABI 3100 genetic analyzer; Applied Biosystems).

\section{Sequencing of genomic DNA samples}

Genomic DNA was extracted from blood samples obtained from individuals analyzed previoulsly by the MLPA method, in order to confirmed the presence of a silent polymorphism at codon 1436 (TCT) encoding Ser to TCC in exon 13 of BRCA1. A 503-bp fragment from $B R C A 1$ was amplified using primers (available on request). Sequencing of this genomic region corresponding to exon 13 was performed with the BigDye ${ }^{\circledR}$ Terminator Cycle Sequencing Kit and analysed on a 3730 automated DNA sequencer (Applied Biosystems, Foster, CA).

\section{RESULTS}

The aim of this study was to estimate the prevalence of rearrangements in the BRCA1 and BRCA2 genes in BRCA1/2 non- 


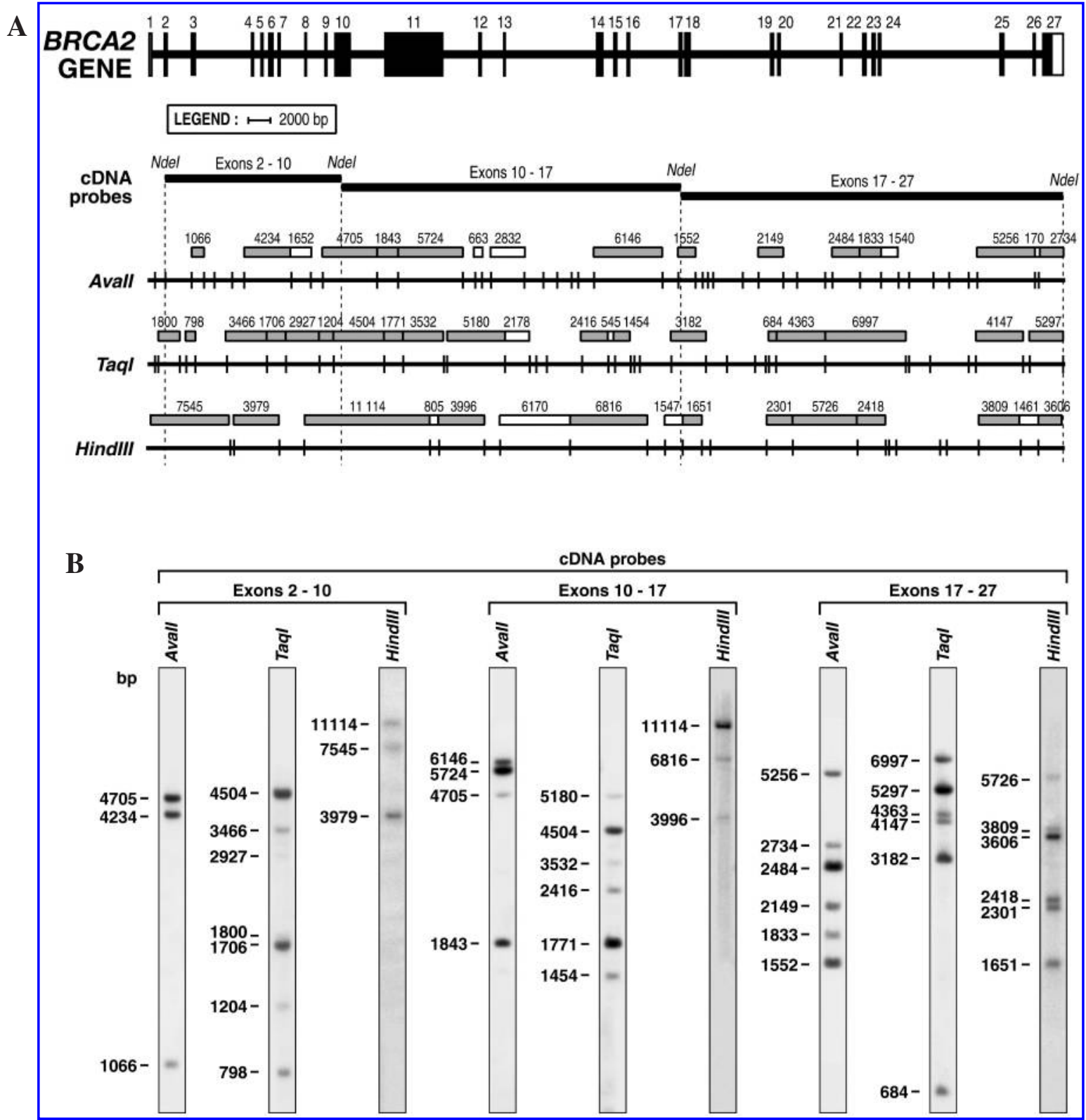

FIG. 2. Southern blot analyses of the $B R C A 2$ gene. A: Restriction sites are indicated on the gene structure and BRCA2 probes used in the Southern blot analyses and sizes (in basepairs [bp]) of restriction fragments expected to be revealed by the probes are indicated in grey boxes. Open boxes represent the fragments not detectable using this Southern blot analysis strategy. B: Results from typical Southern blot analyses of the BRCA2 gene. Fifteen micrograms of genomic DNA was digested with three restriction enzymes for each probes and exposed for 10 days to $\mathrm{x}$-ray single emulsion film with an intensifying screen at $-80^{\circ} \mathrm{C}$.

conclusive high-risk French-Canadian breast and/or ovarian cancer families. Initially, using Southern blotting, we analyzed genomic DNA samples isolated from lymphoblastoid cell lines from 91 affected individuals from 86 families, including 61 individuals from 58 families in which no $B R C A 1 / 2$ deleterious mutation was detected by sequencing approach. The strategy used and typical results obtained from the Southern blot analyses of the BRCA1 (Fig. 1) and BRCA2 (Fig. 2) genes, as well as from reverse transcriptase-polymerase chain reaction (RTPCR) analysis (Fig. 3) are shown in the figures.
In BRCA1, a known polymorphism in exon 16, S1613G (Durocher et al. 1996), creating an AvaII restriction site, is responsible for the restriction fragment length polymorphism (RFLP) observed in 65 chromosomes from 51 individuals (Fig. 4). Screening using cDNA-probes containing BRCAl exons $11-24$, led to the detection of two bands of $4.1 \mathrm{~kb}$ and $3.8 \mathrm{~kb}$ in all tested samples digested with $A v a I I$ and $B g l I I$, respectively. These fragments do not fit the predicted restriction map of $B R C A 1$, and may be explained by the high sequence homology between the $3^{\prime}$ end of BRCA1 exon 24 and a 348-bp segment 


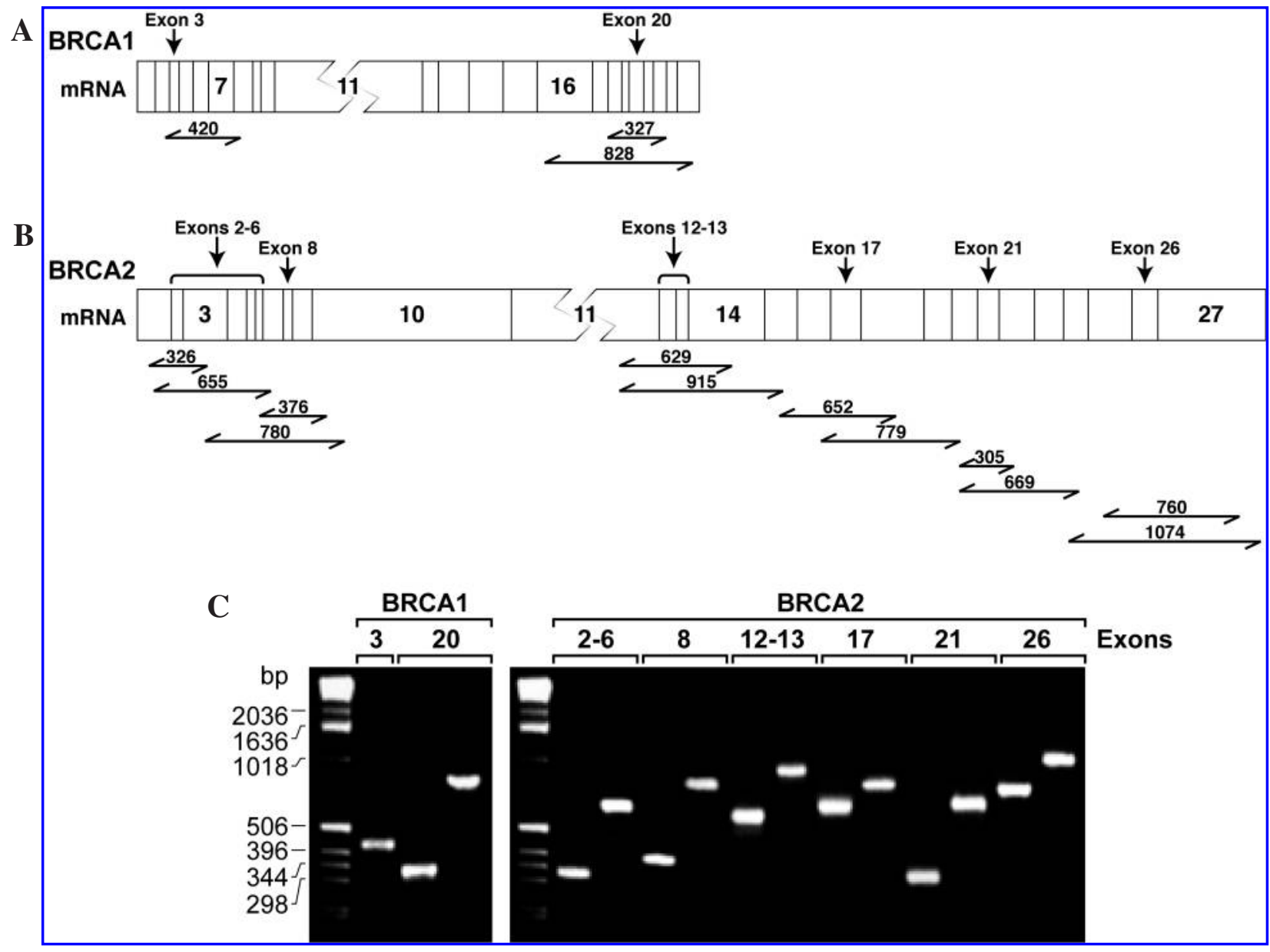

FIG. 3. Confirmation of the presence of small exons by reverse transcriptase-polymerase chain reaction (RT-PCR) analysis for BRCA1 and BRCA2. A and B: Representation of the BRCA1 and BRCA2 mRNA. Detection of exons 3 and 20 for BRCA1, and exons $2-6,8,12,13,17,21$, and 26 for BRCA2. Exons have been amplified twice except BRCA1 exon 3, for all the 91 individuals tested by Southern blot analyses. The arrows under each mRNA represent all the fragments amplified by PCR and their respective length in base pairs (bp). C: Fragments were run on a $2 \%$ agarose gel.

on chromosome 4q28.3 (Stec et al. 2001) (Fig. 5A and 5B). Moreover, supplementary bands of $7.3 \mathrm{~kb}$ and of $10 \mathrm{~kb}$ were observed after digestion with $A v a \mathrm{II}$ and $B g I \mathrm{II}$, respectively, in two individuals (one BRCAl carrier and one from a BRCA1/2 nonconclusive family); these fragments are considered to result from the loss of these restriction sites on the homologous segment on chromosome 4q28 (see Fig. 5A and B).

We performed MLPA analysis for BRCA1 with DNA samples from 154 individuals belonging to the 135 BRCA1/2 nonconclusive families as well as 39 individuals who belong to 32 BRCA1/2-positive families as control. This analysis did not reveal any genomic rearrangements. Nevertheless, a reduction in relative copy number of exon 13 was observed (Fig. 6A) in several individuals. The presence of a previously reported silent polymorphism Ser1436Ser (TCT to TCC) (Durocher et al. 1996) located near the ligation-junction of the two probes of exon 13 was confirmed by direct sequence analysis in each samples in which this false positive from exon 13 was observed. It is of interest to note that currently, a new MLPA kit for BRCA1 is now available (\#P087) and the probe mix contain two sets of probes for exon 13, where one of these is located upstream of this polymorphism in order to avoid such an artefact.

For $B R C A 2$, Southern blot analysis revealed the presence of a frequent polymorphism abolishing an AvaII restriction site in intron 16 (the 6.1-kb band became a $7.5-\mathrm{kb}$ band), which was observed in 28 heterozygous individuals (Fig. 7A). Another rare RFLP has been detected in one heterozygote by using BRCA2 exons 17-27 probe caused by the creation of a new TaqI site 2388 nucleotides following the stop codon that converts the 5.3-kb band into a $4.9-\mathrm{kb}$ band (Fig. 7B). An AvaII RFLP was found with the same probe in three samples, as revealed by an additional $2.5-\mathrm{kb}$ band (data not shown). This RFLP is most likely not pathogenic, because (1) no RFLP was found with TaqI and HindIII when using the same probe (2) no evidence of exon deletion/duplication was detected by MLPA in these individuals (Fig. 6E-6G), and (3) two of these samples were isolated from noncarrier individuals who belong to two different $B R C A 1$-positive families, which were used as reference control group, thus supporting that the familial aggregation of cancer cases is not caused by this RFLP, but is 


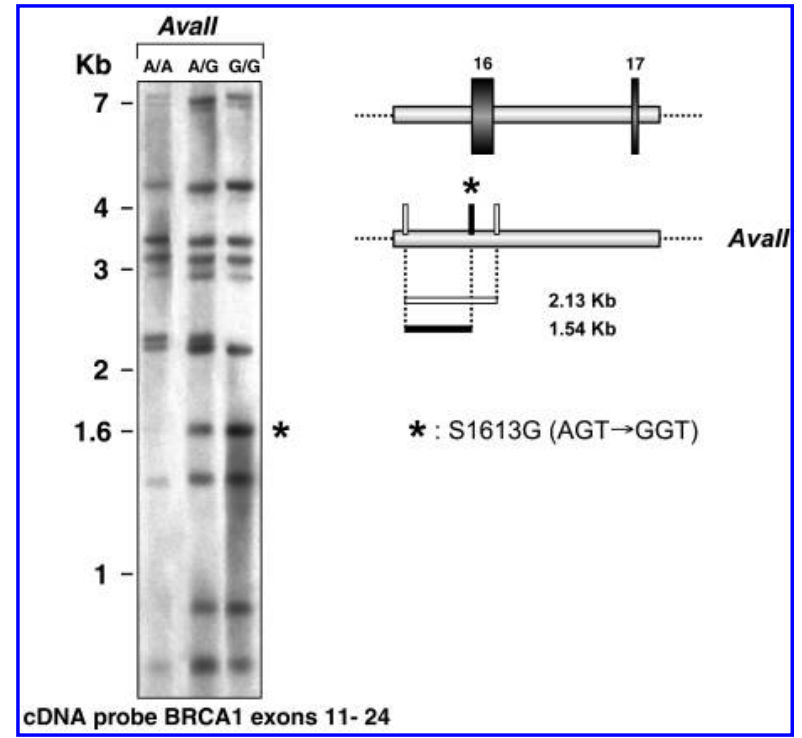

FIG. 4. An AvaII restriction fragment length polymorphism (RFLP) observed with the BRCAI cDNA probe covering exons 11 to 24 due to the known polymorphism S1613G. The additional $1.54 \mathrm{~kb}(\star)$ band is generated because of the creation of AvaII restriction site in exon 16 of BRCA1. Genomic DNA, isolated from a lymphoblastoid cell line, was digested with AvaII and hybridized with a cDNA probe containing exons 11-24. The first lane represents a homozygous individual; the second lane a heterozygous individual; the third an individual homozygous for the polymorphism.

rather explained by the presence of $B R C A 1 \mathrm{R} 1443 \mathrm{X}$ or 2080insA deleterious mutations.

An RFLP generating an additional $10 \mathrm{~kb}$ band observed with HindIII digestion using a probe covering BRCA2 exons 2-10 was detected in one affected individual from a $B R C A 1 / 2$ nonconclusive family (data not shown). No RFLP was found with TaqI and AvaII. Extensive PCR-based analysis using a cDNA sample and combination of 11 differents primers (19 amplicons) failed to detect deletion/duplication in the region covering exons 2 to 10 of the mRNA. Moreover, the presence of all known HindIII restriction sites in the genomic sequence generating the three fragments of 7.5, 3.9, and $11 \mathrm{~kb}$, respectively (Fig. 2A), were confirmed by sequencing. The DNA sample from this patient has been fully sequenced for all exons as well as exon-intron junctions for $B R C A 1$ and $B R C A 2$ and more importantly no evidence of rearrangement was observed by MLPA analysis in this region (Fig. 6H). We cannot exclude the possibility that these RFLPs (AvaII $2.5 \mathrm{~kb}$ and HindIII 10kb) are caused by an artefact. Indeed, one potential disadvantage of using DNA samples extracted from lymphoblastoid cell lines is well illustrated by our observation that anomalous bands appearing using DNA isolated from a lymphoblastoid cell line were not observed when using DNA isolated from leucocytes of the same individual (Fig. 8). Finally, the BRCA2 MLPA analysis has not revealed any genomic rearrangements in all 193 individuals tested.

Assuming a Poisson distribution for the frequency of rearrangements in the French-Canadian population, we can cal- culate the probability of finding no such rearrangements in a sample of 135 fully sequenced $B R C A 1 / 2$ nonconclusive families. If the frequency of MLPA-detectable rearrangements in our cohort of 135 BRCA1/2 nonconclusive families was $2.2 \%$ or higher, we would have had a $95 \%$ or greater chance of observing at least one such rearrangement.

\section{DISCUSSION}

We have analyzed 154 individuals from all the 135 high-risk $B R C A 1 / 2$ French-Canadian breast and/or ovarian cancer families for large deletions/duplications in BRCA1 and BRCA2 genes, in

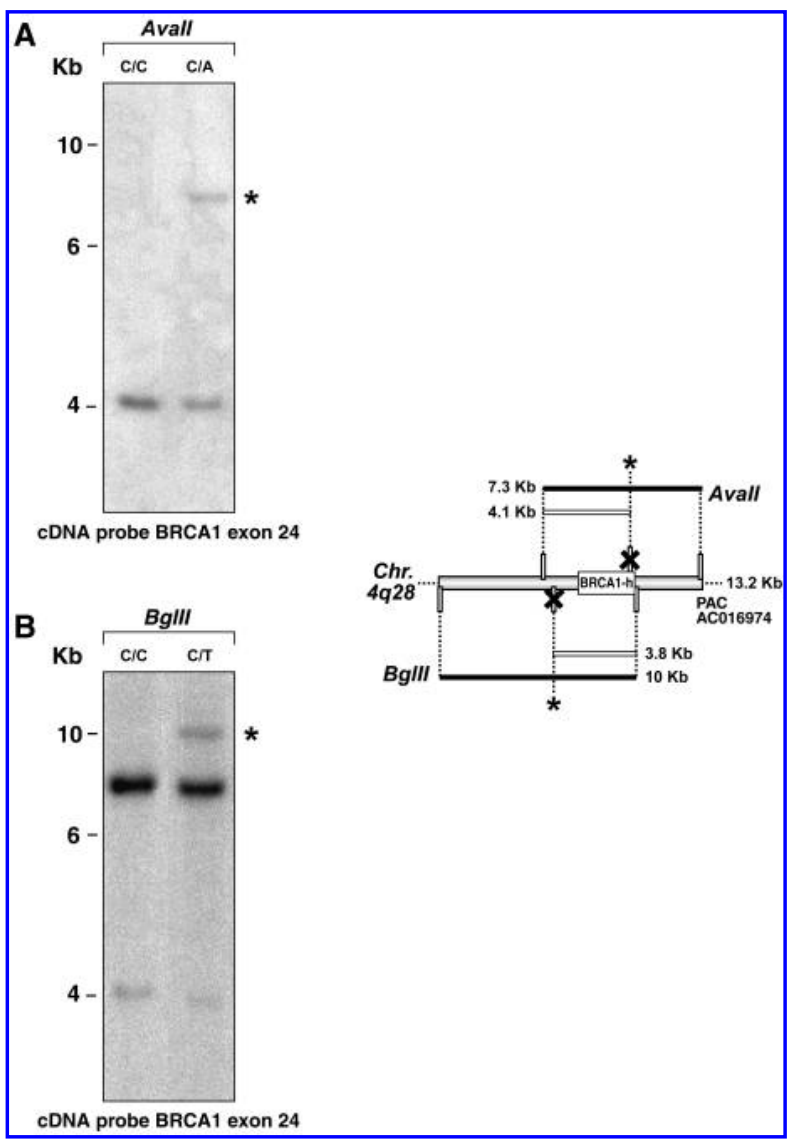

FIG. 5. The high sequence similarity between the $3^{\prime}$ end of $B R C A 1$ and a segment on chromosome $4 \mathrm{q} 28$ is responsible for the additional AvaII and $B g l \mathrm{II}$ restriction fragment length polymorphisms (RFLPs) observed using the BRCAl exon 24 probe. Genomic DNA, isolated from a lymphoblastoid cell line, was digested with $A v a I I$ and $B g l I I$ and hybridized with cDNA probe covering exon 24 . The aberrant $3.8 \mathrm{~kb}$ and $4.1 \mathrm{~kb}$ bands in all tested samples digested with $A v a I I$ and $B g l I I$ did not fit the predicted restriction map of $B R C A 1$ and may be explained by the high sequence similarity between the $3^{\prime}$ end of BRCA1 exon 24 and a 348-bp segment on chromosome $4 \mathrm{q} 28$. The supplementary bands $(\star)$ of $7.3 \mathrm{~kb}(\mathbf{A})$ and of $10 \mathrm{~kb}(\mathbf{B})$ observed after digestion with $A v a I I$ and $B g l I I$, are caused by the loss of these restriction sites on the homologous segment on chromosome 4q28 (GenBank reference sequence AF231509.1) and were confirmed by sequencing this genomic region (data not shown). 


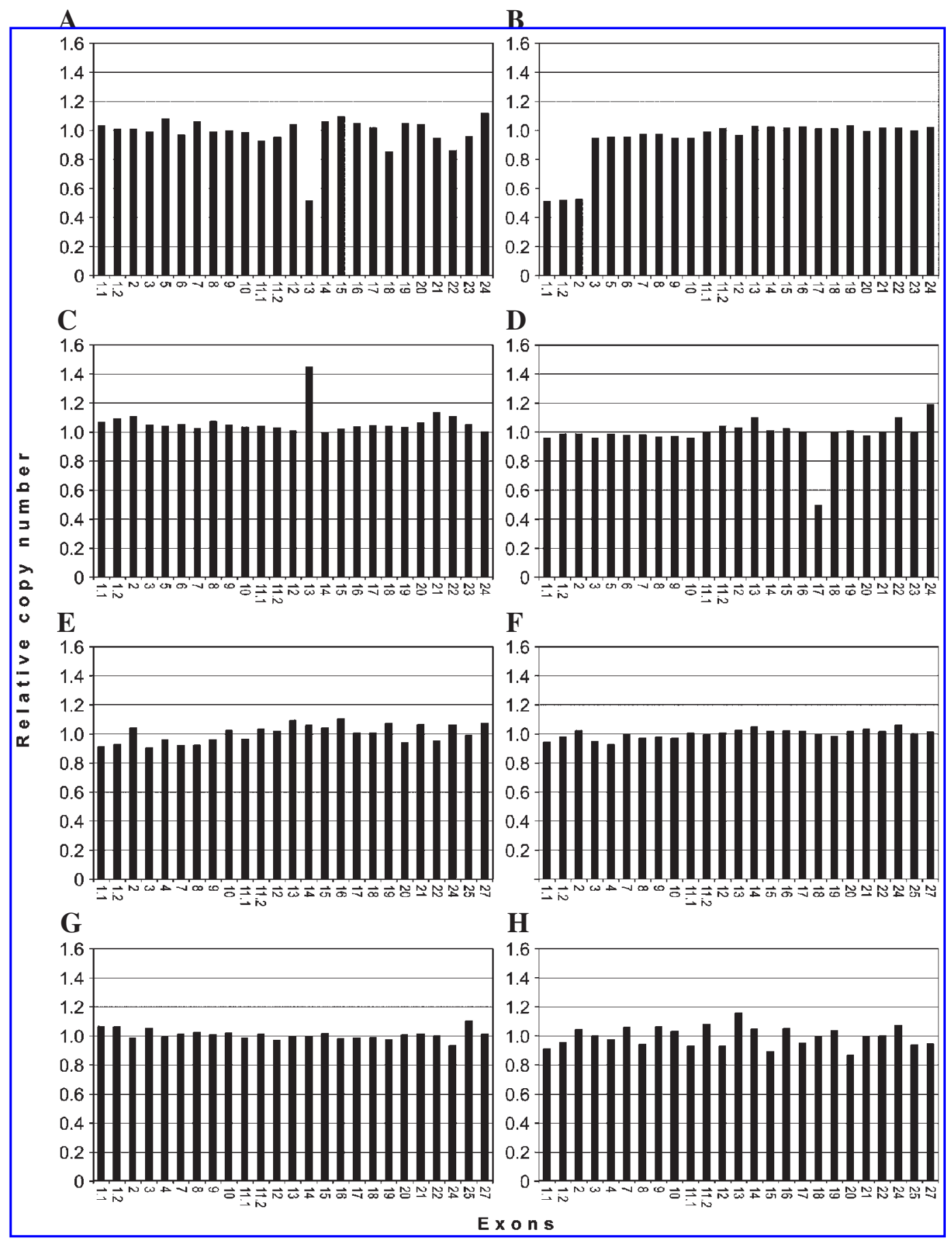

FIG. 6. Typical results obtained after $B R C A 1$ and $B R C A 2$ multiplex ligation probe amplification (MLPA) analyses. A: $B R C A 1$ MLPA analysis illustrating a false-positive signal for exon 13 caused by a polymorphism in codon Ser 1436 (TCT to TCC) affecting the ligation of the probe covering this exon. B: BRCA1 MLPA analysis of a control individual carrying a deletion of exons 1a-1b-2 (Puget et al. 2002). C: BRCA1 MLPA analysis of a control individual carrying a duplication of exon 13 (Puget et al. 1999a). D: BRCA1 MLPA analysis of a control individual carrying a deletion of exon 17 (Puget et al. 1997). E, F, and G: BRCA2 MLPA analyses of the three individuals having an 2.5-kb AvaII RFLP using BRCA2 exons 17-27 probe by Southern blot. H: BRCA2 MLPA analysis of the individual having a 10-kb HindIII RFLP using BRCA2 exons 2-10 probe by Southern blot.

which no mutations in these genes were found by a previous twostep PCR-based sequencing approach. Because no rearrangements were identified in either gene, such large rearrangements must be quite rare in the French-Canadian population.
The lack of large deletions in BRCA2 French-Canadian families is consistent with previous results from other populations, such as the Finnish and Dutch (Lahti-Domenici et al. 2001; Peelen et al. 2000). To our knowledge, only 11 BRCA2 rearrange- 


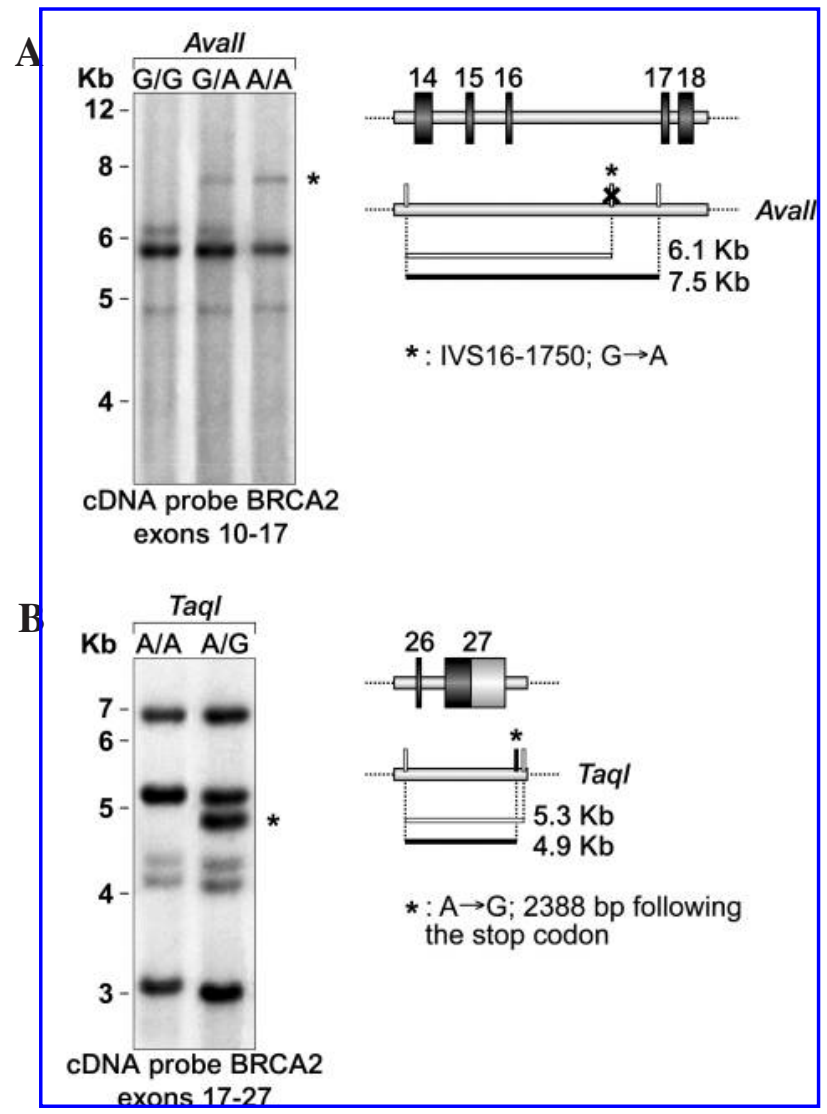

FIG. 7. Characterization of the AvaII and the TaqI restriction fragment length polymorphisms (RFLPs) observed with the $B R C A 2$ cDNA probe covering exons 10 to 17 and 17 to 27 , respectively. A: cDNA probe covering exons 10 to 17 of $B R C A 2$ showing a supplementary 7.5 -kb band $(\star$ ) caused by the loss of the AvaII restriction site in intron 16 (IVS16-1750; G $\rightarrow$ A). The first lane represents a homozygous individual; the second lane a heterozygous individual; the third a homozygous individual for the polymorphism. B: An additional TaqI restriction site located 2388 nucleotides following the stop codon of BRCA2 modifies the length of the $5.3-\mathrm{kb}$ band to a $4.9-\mathrm{kb}(\star)$ fragment. Only found in one heterozygous individual.

ments have been reported: 9 deletions (Agata et al. 2005; Nordling et al. 1998; Tournier et al. 2004; Wang et al. 2001; Woodward et al. 2005), 1 duplication (Tournier et al. 2004) and an insertion of an Alu element into exon 22, which resulted in alternative splicing that skipped exon 22 (Miki et al. 1996). Two of these studies have analyzed families with at least one male breast cancer and found rearrangements in $7.7 \%$ and $12 \%$ (Tournier et al. 2004; Woodward et al. 2005). Because BRCA2 defects are more frequent in families with cases of male breast cancer, it may be useful to test for BRCA2 gene rearrangements in these families.

However, for $B R C A 1$, inherited large genomic rearrangements appear to be relatively common. Indeed, more than 30 different BRCAl rearrangements have been reported and 29 have mapped breakpoints (Mazoyer 2005). Two of them account for $36 \%$ of all BRCA1 mutations found in high-risk Dutch breast-cancer families (Petrij-Bosch et al. 1997) and genomic rearrangement represent $11.6 \%, 15 \%$, and $40 \%$ of all BRCA1 deleterious mutations in a group of French, American, and Italian breast and ovarian cancer families, respectively (Gad et al. 2002; Montagna et al. 2003; Puget et al. 1999a, 1999b). It is important to note that although some studies have reported a high percentage of families with chromosomal rearrangements in $B R C A 1$, this proportion should be taken with caution because some of these families were selected based on a positive linkage to the BRCA1 locus or by using a highly selective operational criteria (Montagna et al. 2003; Puget et al. 1999b).

One of the most well-known founder mutations is probably the BRCAl exon 13 duplication (ins6kbEx13), distributed mainly in English-speaking countries with historical links to Britain (BRCA1 Exon 13 Duplication Screening Group 2000). This founder mutation was observed six times in Canadian English-speaking families and absent in 1749 families who were screened in non-English-speaking countries, including 45 from our French-Canadian cohort. All exon 13-duplication carriers share the same haplotype supporting the founder effect. A recent study characterized the prevalence of five specific rearrangement mutations in a large North American patient population (Hendrickson et al. 2005). The five mutations accounted

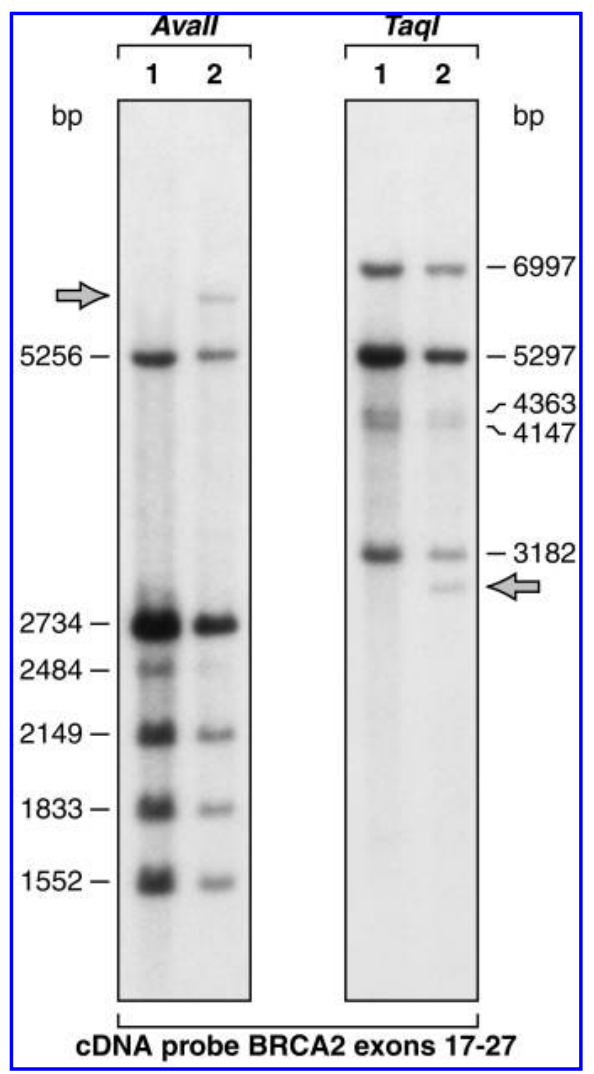

FIG. 8. Additional anomalous $A v a \mathrm{II}$ and $T a q \mathrm{I}$ bands with $B R C A 2$ cDNA probe covering exons 17 to 27 are only observed using a lymphoblastoid cell line. Lane 1 represents the digestion of genomic DNA extracted from fresh leukocytes compared to lane 2, which represents digestion of the DNA isolated from a lymphoblastoid cell line of the same individual. When digested with $A v a \mathrm{II}$, an additional band at $6.5 \mathrm{~Kb}$ appears, while the TaqI digestion revealed an additional $2.5-\mathrm{kb}$ band only in the lymphoblastoid cell line of the same individual. 
for $4.34 \%$ of deleterious BRCA1 mutations identified in 20,712 hereditary breast/ovarian cancer patients undergoing genetic testing in North America.

New complementary and/or alternative strategies have been developed over past few years that allow detection of rearrangements missed by one or another techniques because of their respective limitations, including: quantitative multiplex PCR of short fluorescent fragments (QMPSF) (Casilli et al. 2002), DNA array-based method (Favis et al. 2000; Frolov et al. 2002), color bar code on combed DNA (Casilli et al. 2002), semiquantitative multiplex PCR (Hofmann et al. 2003), MLPA (Schouten et al. 2002), real-time PCR (Barrois et al. 2004), and single nucleotide polymorphism (SNP) haplotype analysis (Ward et al. 2005). Knowing limitations of Southern and MLPA analyses used in the present study, we cannot exclude the possibility that rearrangement(s) could have been missed in our tested population. For example, the false-negative results would involve small portions of exons because only short sequence stretches are targeted in each exon with MLPA and very small rearrangements might potentially be missed by Southern blot analysis if they occurred in a large restriction fragment. In order to avoid such an event, long-range PCR (LR-PCR) could be used to confirm the integrity of the genomic sequence as well as RT-PCR analysis to confirm the integrity of transcripts. Note that when using cDNA, it should be relevant to inhibit nonsense-mediated mRNA decay prior to RNA extraction.

In this study using French-Canadian families, no large deletion/duplication or other rearrangement were found in BRCAI and $B R C A 2$, thus suggesting that the frequency of such mutations is quite low in our population. This implies that the PCR-based sequencing approach for $B R C A 1 / 2$ predictive testing in this population will be highly sensitive. Nevertheless, the possibility of occurrence of large deletions/duplications or other rearrangements in French-Canadian families from other regions in Canada should be kept in mind (Carson et al. 1999). Moreover, it should be mentioned that although index cases were referred from almost all regions of the province of Quebec, the majority of high risk families tested in the present study have been recruited from East of Quebec (Simard et al., unpublished data); thus the existence of some recurrent mutations more frequent in other regions of Quebec, such as the Montreal region, remains a possibility. The demographic history of Quebec helps to explain why the distribution of mutation spectra for several diseases is unique to the province of Quebec (Scriver 2001).

Taking into consideration the numerous advantages of MLPA analyses, it would seem appropriate to use this approach to complement PCR-based sequencing to decrease as much as possible the occurrence of false-negative results, thus improving the clinical validity of the predictive $B R C A 1 / 2$ test.

\section{ACKNOWLEDGMENTS}

The authors are indebted to the participants for their generosity and providing DNA samples. We would also like to thanks Lucie Larouche, Gilles Leblanc, Martine Tranchant for skillful technical assistance; Claire Brousseau, Marie-Andrée Lajoie, Pascale Léger, Hélène Malouin, Josée Rhéaume, Dr. Sylvie Délos, Nathalie Bolduc, Andrée McMillan, and Tina
Babineau for genetic counseling and clinical data management. We would like to thank Leanne Yunker from the Molecular Diagnostic Laboratory, Alberta Children's Hospital who tested some samples by MLPA. We would like to thank Professor Bartha Maria Knoppers and her colleagues from the Centre de recherche en droit public de l'Université de Montréal for their valuable help for ELSI issues related to our research program. We also greatly appreciate advice received from ethics committees. This work was supported by the Canadian Institutes of Health Research (CIHR) for the INHERIT BRCAs research program, Fonds de la Recherche en Santé du Québec (FRSQ)/ Réseau de Médecine Génétique Appliquée (RMGA), and the Canadian Breast Cancer Research Alliance. A.-M.M. is a recipient of a studentship from CIHR, and J.S. is Chairholder of the Canada Research Chair in Oncogenetics.

\section{REFERENCES}

Agata S, Dalla Palma M, Callegaro M, Scaini MC, Menin C, Ghiotto C, Nicoletto O, Zavagno G, Chieco-Bianchi L, D'Andrea E, Montagna M (2005) Large genomic deletions inactivate the BRCA2 gene in breast cancer families. J Med Genet 42:e64.

Avard D, Bridge P, Bucci LM, Chiquette J, Dorval M, Durocher F, Easton D, Godard B, Goldgar D, Knoppers BM, Laframboise R, Lespérance B, Plante M, Tavtigian S, Vézina H, Wilson B, BRCAs I, Simard J (2006) Partnering in Oncogenetics Research-The INHERIT BRCAs Experience: Opportunities and challenges. Fam Cancer 5:3-13.

Barrois M, Bieche I, Mazoyer S, Champeme MH, Bressac-de Paillerets B, Lidereau R (2004) Real-time PCR-based gene dosage assay for detecting BRCA1 rearrangements in breast-ovarian cancer families. Clin Genet 65:131-136.

BRCA1 Exon 13 Duplication Screening Group (2000) The exon 13 duplication in the BRCA1 gene is a founder mutation present in geographically diverse populations. The BRCA1 Exon 13 Duplication Screening Group. Am J Hum Genet 67:207-212.

Carson N, Gilpin C, Hunter A, Allanson J, Aubry H (1999) An in frame deletion of BRCA1 exon 20 in a family with early onset breast cancer and ovarian cancer. Paper presented at 49th Annual Meeting of the American Society of Human Genetics. Moscone Center in San Francisco, California, October 19-23, 1999.

Casilli F, Di Rocco ZC, Gad S, Tournier I, Stoppa-Lyonnet D, Frebourg T, Tosi M (2002) Rapid detection of novel BRCA1 rearrangements in high-risk breast-ovarian cancer families using multiplex PCR of short fluorescent fragments. Hum Mutat 20:218-226.

Del Sal G, Manfioletti G, Schneider C (1989) The CTAB-DNA precipitation method: A common mini-scale preparation of template DNA from phagemids, phages or plasmids suitable for sequencing. Biotechniques 7:514-520.

Durocher F, Shattuck-Eidens D, McClure M, Labrie F, Skolnick MH, Goldgar DE, Simard J (1996) Comparison of BRCA1 polymorphisms, rare sequence variants and/or missense mutations in unaffected and breast/ovarian cancer populations. Hum Mol Genet 5:835-842.

Favis R, Day JP, Gerry NP, Phelan C, Narod S, Barany F (2000) Universal DNA array detection of small insertions and deletions in BRCA1 and BRCA2. Nat Biotechnol 18:561-564.

Frolov A, Prowse AH, Vanderveer L, Bove B, Wu H, Godwin AK (2002) DNA array-based method for detection of large rearrangements in the BRCA1 gene. Genes Chromosomes Cancer 35:232-241.

Gad S, Caux-Moncoutier V, Pages-Berhouet S, Gauthier-Villars M, Coupier I, Pujol P, Frenay M, Gilbert B, Maugard C, Bignon YJ, 
Chevrier A, Rossi A, Fricker JP, Nguyen TD, Demange L, Aurias A, Bensimon A, Stoppa-Lyonnet D (2002) Significant contribution of large BRCA1 gene rearrangements in 120 French breast and ovarian cancer families. Oncogene 21:6841-6847.

Hendrickson BC, Judkins T, Ward BD, Eliason K, Deffenbaugh AE, Burbidge LA, Pyne K, Leclair B, Ward BE, Scholl T (2005) Prevalence of five previously reported and recurrent BRCA1 genetic rearrangement mutations in 20,000 patients from hereditary breast/ ovarian cancer families. Genes Chromosomes Cancer 43:309-313.

Hofmann W, Gorgens H, John A, Horn D, Huttner C, Arnold N, Scherneck S, Schackert HK (2003) Screening for large rearrangements of the BRCA1 gene in German breast or ovarian cancer families using semi-quantitative multiplex PCR method. Hum Mutat 22:103-104.

Key TJ, Verkasalo PK, Banks E (2001) Epidemiology of breast cancer. Lancet Oncol 2:133-140

Lacey JV Jr, Devesa SS, Brinton LA (2002) Recent trends in breast cancer incidence and mortality. Environ Mol Mutagen 39:82-88.

Lahti-Domenici J, Rapakko K, Paakkonen K, Allinen M, Nevanlinna H, Kujala M, Huusko P, Winqvist R (2001) Exclusion of large deletions and other rearrangements in BRCA1 and BRCA2 in Finnish breast and ovarian cancer families. Cancer Genet Cytogenet 129: $120-123$.

Lichtenstein P, Holm NV, Verkasalo PK, Iliadou A, Kaprio J, Koskenvuo M, Pukkala E, Skytthe A, Hemminki K (2000) Environmental and heritable factors in the causation of cancer-Analyses of cohorts of twins from Sweden, Denmark, and Finland. N Engl J Med 343: $78-85$.

Mazoyer S (2005) Genomic rearrangements in the BRCA1 and BRCA2 genes. Hum Mutat 25:415-422.

Miki Y, Katagiri T, Kasumi F, Yoshimoto T, Nakamura Y (1996) Mutation analysis in the BRCA2 gene in primary breast cancers. Nat Genet 13:245-247.

Miki Y, Swensen J, Shattuck-Eidens D, Futreal PA, Harshman K, Tavtigian S, Liu Q, Cochran C, Bennett LM, Ding W, Bell R, Rosenthal J, Hussey C, Tran T, McClure M, Frye C, Hattier T, Phelps R, Haugen-Strano A, Katcher H, Yakumo K, Gholami Z, Shaffer D, Stone S, Bayer S, Wray C, Bogden R, Dayanath P, Ward J, Tonin P, Narod S, Bristow P, Norris F, Helvering L, Morrison P, Rosteck P, Lai M, Barrett JC, Lewis C, Neuhausen S, Cannon-Albright L, Goldgar D, Wiseman R, Kamb A and Skolnick M (1994) A strong candidate for the breast and ovarian cancer susceptibility gene BRCA1. Science 266:66-71.

Montagna M, Palma MD, Menin C, Agata S, De Nicolo A, ChiecoBianchi L, D'Andrea E (2003) Genomic rearrangements account for more than one-third of the BRCA1 mutations in northern Italian breast/ovarian cancer families. Hum Mol Genet 12:1055-1061.

Nordling M, Karlsson P, Wahlstrom J, Engwall Y, Wallgren A, Martinsson $\mathrm{T}$ (1998) A large deletion disrupts the exon 3 transcription activation domain of the BRCA2 gene in a breast/ovarian cancer family. Cancer Res 58:1372-1375.

Pavlicek A, Noskov VN, Kouprina N, Barrett JC, Jurka J, Larionov V (2004) Evolution of the tumor suppressor BRCA1 locus in primates: Implications for cancer predisposition. Hum Mol Genet 13:27372751.

Peelen T, van Vliet M, Bosch A, Bignell G, Vasen HF, Klijn JG, Meijers-Heijboer H, Stratton M, van Ommen GJ, Cornelisse CJ, Devilee P (2000) Screening for BRCA2 mutations in 81 Dutch breast-ovarian cancer families. Br J Cancer 82:151-156.

Peto J (2001) Cancer epidemiology in the last century and the next decade. Nature 411:390-395.

Petrij-Bosch A, Peelen T, van Vliet M, van Eijk R, Olmer R, Drusedau M, Hogervorst FB, Hageman S, Arts PJ, Ligtenberg MJ, MeijersHeijboer H, Klijn JG, Vasen HF, Cornelisse CJ, van't Veer LJ, Bakker E, van Ommen GJ, Devilee P (1997) BRCA1 genomic deletions are major founder mutations in Dutch breast cancer patients. Nat Genet 17:341-345.
Pisani P, Parkin DM, Bray F, Ferlay J (1999) Estimates of the worldwide mortality from 25 cancers in 1990. Int J Cancer 83:18-29.

Puget N, Gad S, Perrin-Vidoz L, Sinilnikova OM, Stoppa-Lyonnet D, Lenoir GM, Mazoyer S (2002) Distinct BRCA1 rearrangements involving the BRCA1 pseudogene suggest the existence of a recombination hot spot. Am J Hum Genet 70:858-865.

Puget N, Sinilnikova OM, Stoppa-Lyonnet D, Audoynaud C, Pages S, Lynch HT, Goldgar D, Lenoir GM, Mazoyer S (1999a) An Alu-mediated 6-kb duplication in the BRCA1 gene: A new founder mutation? Am J Hum Genet 64:300-302.

Puget N, Stoppa-Lyonnet D, Sinilnikova OM, Pages S, Lynch HT, Lenoir GM, Mazoyer S (1999b) Screening for germ-line rearrangements and regulatory mutations in BRCA1 led to the identification of four new deletions. Cancer Res 59:455-461.

Puget N, Torchard D, Serova-Sinilnikova OM, Lynch HT, Feunteun J, Lenoir GM, Mazoyer S (1997) A 10-kb Alu-mediated germ-line deletion removing BRCA1 exon 17. Cancer Res 57:828-831.

Schouten JP, McElgunn CJ, Waaijer R, Zwijnenburg D, Diepvens F, Pals G (2002) Relative quantification of 40 nucleic acid sequences by multiplex ligation-dependent probe amplification. Nucleic Acids Res 30:e57.

Scriver CR (2001) Human genetics: lessons from Quebec populations. Annu Rev Genomics Hum Genet 2:69-101.

Simard J, Dumont M, Moisan AM, Durocher F, Laframboise R, Plante M, Chiquette J, Lespérance B, Pichette R, Lépine J, Bessette P, Voyer P, Bridge P, Goldgar D, BRCAs I (2004) Molecular epidemiology of BRCA1 and BRCA2 mutations in French-Canadian breast/ovarian families. Paper presented at The American Society of Human Genetics. Toronto, October 26-30, 2004.

Simard J, Joly Y, Durocher F, Knoppers BM, BRCAs I (2005) Les enjeux éthiques du partage des résultats de recherche: L'expérience d'INHERIT BRCAs. In: Pilips-Nootens S, Godard B, Knoppers BM, Régnier MH (eds) La recherche en génétique et en génomique: Droits et responsabilités. Les Éditions Thémis, Montréal, Canada, pp. 103-139.

Smith TM, Lee MK, Szabo CI, Jerome N, McEuen M, Taylor M, Hood L, King MC (1996) Complete genomic sequence and analysis of 117 $\mathrm{kb}$ of human DNA containing the gene BRCA1. Genome Res 6:1029-1049.

Stec I, van Vliet M, van Eijk R, Meijers H, Kroeze KH, Dauwerse JG, van Ommen GJ, Cornelisse CJ, den Dunnen JT, Devilee P (2001) A partial BRCA1 sequence homology mapping to 4q28. Cytogenet Cell Genet 94:26-29.

Tavtigian SV, Simard J, Rommens J, Couch F, Shattuck-Eidens D, Neuhausen S, Merajver S, Thorlacius S, Offit K, Stoppa-Lyonnet D, Belanger C, Bell R, Berry S, Bogden R, Chen Q, Davis T, Dumont M, Frye C, Hattier T, Jammulapati S, Janecki T, Jiang P, Kehrer R, Leblanc JF, Mitchell JT, McArthur-Morrison J, Nguyen K, Peng Y, Samson C, Schroeder M, Snyder SC, Steele L, Stringfellow M, Stroup C, Swedlund B, Swense J, Teng D, Thomas A, Tran T, Tranchant M, Weaver-Feldhaus J, Wong AK, Shizuya H, Eyfjord JE, Cannon-Albright L, Tranchant M, Labrie F, Skolnick MH, Weber B, Kamb A, Goldgar DE (1996) The complete BRCA2 gene and mutations in chromosome 13q-linked kindreds. Nat Genet 12:333-337.

Tournier I, Paillerets BB, Sobol H, Stoppa-Lyonnet D, Lidereau R, Barrois M, Mazoyer S, Coulet F, Hardouin A, Chompret A, Lortholary A, Chappuis P, Bourdon V, Bonadona V, Maugard C, Gilbert B, Nogues C, Frebourg T, Tosi M (2004) Significant contribution of germline BRCA2 rearrangements in male breast cancer families. Cancer Res 64:8143-8147.

Wang T, Lerer I, Gueta Z, Sagi M, Kadouri L, Peretz T, Abeliovich D (2001) A deletion/insertion mutation in the BRCA2 gene in a breast cancer family: A possible role of the Alu-polyA tail in the evolution of the deletion. Genes Chromosomes Cancer 31:91-95.

Ward BD, Hendrickson BC, Judkins T, Deffenbaugh AM, Leclair B, Ward BE, Scholl T (2005) A multi-exonic BRCA1 deletion identi- 
fied in multiple families through single nucleotide polymorphism haplotype pair analysis and gene amplification with widely dispersed primer sets. J Mol Diagn 7:139-142.

Woodward AM, Davis TA, Silva AG, Kirk JA, Leary JA (2005) Large genomic rearrangements of both BRCA2 and BRCA1 are a feature of the inherited breast/ovarian cancer phenotype in selected families. J Med Genet 42:e31.

Wooster R, Bignell G, Lancaster J, Swift S, Seal S, Mangion J, Collins N, Gregory S, Gumbs C, Micklem G (1995) Identification of the breast cancer susceptibility gene BRCA2. Nature 378:789-792.
Address reprint requests to:

Dr. Jacques Simard

Cancer Genomics Laboratory, T3-57

Oncology and Molecular Endocrinology Research Center

CHUQ, 2705 Laurier Boulevard

Quebec City G1V 452

Canada

E-mail: jacques.simard@crchul.ulaval.ca 


\section{This article has been cited by:}

1. Jesús Valle, Lídia Feliubadaló, Marga Nadal, Alex Teulé, Rosa Miró, Raquel Cuesta, Eva Tornero, Mireia Menéndez, Esther Darder, Joan Brunet, Gabriel Capellà, Ignacio Blanco, Conxi Lázaro. 2009. Identification and comprehensive characterization of large genomic rearrangements in the BRCA1 and BRCA2 genes. Breast Cancer Research and Treatment. [CrossRef]

2. P Ghadirian, A Robidoux, P Zhang, R Royer, M Akbari, S Zhang, E Fafard, M Costa, G Martin, C Potvin, E Patocskai, N Larouche, R Younan, E Nassif, S Giroux, SA Narod, F Rousseau, WD Foulkes. 2009. The contribution of founder mutations to early-onset breast cancer in French-Canadian women. Clinical Genetics 76:5, 421-426. [CrossRef]

3. Tal Distelman-Menachem, Tal Shapira, Yael Laitman, Bella Kaufman, Frida Barak, Sean Tavtigian, Eitan Friedman. 2009. Analysis of BRCA1/BRCA2 genes' contribution to breast cancer susceptibility in high risk Jewish Ashkenazi women. Familial Cancer 8:2, 127-133. [CrossRef]

4. Thomas v. O. Hansen, Lars Jønson, Anders Albrechtsen, Mette K. Andersen, Bent Ejlertsen, Finn C. Nielsen. 2009. Large BRCA1 and BRCA2 genomic rearrangements in Danish high risk breast-ovarian cancer families. Breast Cancer Research and Treatment 115:2, 315-323. [CrossRef]

5. Mario Falchetti, Ramona Lupi, Piera Rizzolo, Ketty Ceccarelli, Ines Zanna, Valentina Calò, Stefania Tommasi, Giovanna Masala, Angelo Paradiso, Alberto Gulino, Giuseppe Giannini, Antonio Russo, Domenico Palli, Laura Ottini. 2008. BRCA1/BRCA2 rearrangements and CHEK2 common mutations are infrequent in Italian male breast cancer cases. Breast Cancer Research and Treatment 110:1, 161-167. [CrossRef]

6. Frédéric Guénard, Yvan Labrie, Geneviève Ouellette, Charles Joly Beauparlant, Jacques Simard, Francine Durocher. 2008. Mutational analysis of the breast cancer susceptibility gene BRIP1 /BACH1/FANCJ in high-risk non-BRCA1/BRCA2 breast cancer families. Journal of Human Genetics 53:7, 579-591. [CrossRef]

7. Sylvie Desjardins, Pascal Belleau, Yvan Labrie, Geneviève Ouellette, Paul Bessette, Jocelyne Chiquette, Rachel Laframboise, Jean Lépine, Bernard Lespérance, Roxane Pichette, Marie Plante, Francine Durocher. 2008. Genetic variants and haplotype analyses of the ZBRK1/ZNF350 gene in high-risk non BRCA1/2 French Canadian breast and ovarian cancer families. International Journal of Cancer 122:1, 108-116. [CrossRef]

8. Patricia N. Tonin, Christine M. Maugard, Chantal Perret, Anne-Marie Mes-Masson, Diane M. Provencher. 2007. A review of histopathological subtypes of ovarian cancer in BRCA-related French Canadian cancer families. Familial Cancer 6:4, $491-497$. [CrossRef]

9. Sara Gutiérrez-Enríquez, Miguel La Hoya, Cristina Martínez-Bouzas, Ana Sanchez Abajo, Teresa Ramón y Cajal, Gemma Llort, Ignacio Blanco, Elena Beristain, Eduardo Díaz-Rubio, Carmen Alonso, María-Isabel Tejada, Trinidad Caldés, Orland Diez. 2007. Screening for large rearrangements of the BRCA2 gene in Spanish families with breast/ovarian cancer. Breast Cancer Research and Treatment 103:1, 103-107. [CrossRef]

10. Béatrice Godard, Annabelle Pratte , Martine Dumont , Adèle Simard-Lebrun , Jacques Simard . 2007. Factors Associated with an Individual's Decision to Withdraw from Genetic Testing for Breast And Ovarian Cancer Susceptibility: Implications for CounselingFactors Associated with an Individual's Decision to Withdraw from Genetic Testing for Breast And Ovarian Cancer Susceptibility: Implications for Counseling. Genetic Testing 11:1, 45-54. [Abstract] [PDF] [PDF Plus] 